\title{
Techniques of Translating Interjection in the Novel "Looking for Alaska" in terms of Functions, Meanings, and Categories
}

\author{
${ }^{1}$ Muhammad Izzul Wahid, ${ }^{2}$ Achmad Basari \\ ${ }^{1,2}$ Universitas Dian Nuswantoro Semarang \\ Email: (achmad.basari@dsn.dinus.ac.id)
}

Article History: Submitted July 25 $5^{\text {th }}, 2020$; Accepted August 24 ${ }^{\text {th }}, 2020$; Published August $30^{\text {th }}, 2020$

\begin{abstract}
The objective of this research is to find out the functions, meanings, and categories of interjections, and the translation technique practiced by the Indonesian translator to translate English interjection found in the novel "Looking for Alaska" or "Mencari Alaska" in Indonesian. This research is adopting a descriptive qualitative, with the novel of "Looking for Alaska" and "Mencari Alaska" as the primary source of the data. Since the data collection of interjections is found in the book, it can be classified as content analysis. The researchers found out that there are six translation techniques used by the translators to translate interjections, six kinds of interjections in terms of functions and meanings, and three kinds of interjections in terms of categories found in the novel. Those six translation techniques are 164 interjections $(41,21 \%)$ for literal translation technique, 49 interjections $(12,31 \%)$ for translation by using an interjection with similar meaning and form technique, 61 interjection $(15,33 \%)$ for translation by using an interjection with different forms, but the same meaning, 11 interjections $(2,76 \%)$ for partly deleted omission technique, 9 interjections $(2,26 \%)$ for total deleted omission technique, 8 interjections $(2,01 \%)$ for addition technique, 58 interjections $(10,80 \%)$ for pure borrowing technique, and 53 interjections $(13,32 \%)$ for naturalized borrowing technique. From the research finding of the interjection regarding functions and meanings, there is a total of 419 types of English interjections where the researchers divided into six classes. Those types of function are: $5(1,19 \%)$ data of interjection are used to greet, 35 $(8,35 \%)$ data of interjection are used to express joy, $57(13,37 \%)$ data of interjection are used to get attention, $169(40,33)$ data of interjection are used to express approval, $120(28,64 \%)$ data of interjection are used to express a surprise, and $34(8,11)$ data of interjection used to express sorrow. Then from the research finding of interjection regarding category, there is a total of 419 data of English interjections where the researchers divided into three classes, those classes are $72(17,18 \%)$ data of primary interjection, $336(80,19 \%)$ data of secondary, and 11 $(2,63 \%)$ data of onomatopoeic interjection. The findings of this study show that the translation techniques mostly used by the translators to translate an English interjection is translation by literal translation and translation by borrowing technique. In contrast, the least used translation technique is the addition technique that the translators rarely used it to translate the interjection.
\end{abstract}

Keywords: interjection, interjection translation, "Looking for Alaska", "Mencari Alaska", translation technique

Abstrak.Tujuan dari penelitian ini adalah untuk mengetahui fungsi, makna, dan kategori kata
seru, serta teknik penerjemahan yang dilakukan oleh penerjemah bahasa Indonesia dalam
menerjemahkan kata seru dalam bahasa Inggris yang terdapat pada novel "Looking for
Alaska" atau "Mencari Alaska" dalam bahasa Indonesia. Penelitian ini bersifat deskriptif
kualitatif dengan novel "Looking for Alaska" dan "Mencari Alaska" sebagai sumber data
utama. Karena pengumpulan data interjeksi terdapat di dalam buku, maka dapat
diklasifikasikan sebagai analisis isi. Peneliti menemukan bahwa ada enam teknik
penerjemahan yang digunakan oleh penerjemah untuk menerjemahkan kata seru, enam jenis
kata seru dari segi fungsi dan makna, dan tiga jenis kata seru dalam kategori yang ditemukan 
dalam novel. Keenam teknik penerjemahan tersebut adalah 164 interjeksi (41,21\%) untuk teknik terjemahan literal, 49 interjeksi (12,31\%) untuk terjemahan dengan menggunakan interjeksi dengan teknik makna dan bentuk yang mirip, 61 interjeksi $(15,33 \%)$ untuk terjemahan oleh menggunakan kata seru dengan bentuk yang berbeda, tetapi artinya sama, 11 kata seru (2,76\%) untuk teknik penghilangan sebagian, 9 kata seru $(2,26 \%)$ untuk teknik penghilangan total yang dihapus, 8 kata seru (2,01\%) untuk penambahan teknik, 58 interjeksi $(10,80 \%)$ untuk teknik peminjaman murni, dan 53 interjeksi (13,32\%) untuk teknik peminjaman yang dinaturalisasi. Dari hasil penelitian interjeksi terkait fungsi dan makna, terdapat total 419 jenis interjeksi bahasa Inggris yang peneliti bagi dalam enam kelas. Jenis fungsi tersebut adalah: 5 (1,19\%) data interjeksi digunakan untuk menyapa, 35 (8,35\%) data interjeksi digunakan untuk mengekspresikan kegembiraan, 57 (13,37\%) data interjeksi digunakan untuk mendapat perhatian, 169 (40,33) data kata seru digunakan untuk menyatakan persetujuan, 120 (28,64\%) data kata seru digunakan untuk menyatakan kejutan, dan $34(8,11)$ data kata seru digunakan untuk menyatakan kesedihan. Kemudian dari hasil penelitian interjeksi kategori interjeksi terdapat total 419 data interjeksi bahasa Inggris dimana peneliti dibagi menjadi tiga kelas yaitu 72 (17,18\%) data interjeksi primer, 336 (80,19\%) data interjeksi bahasa Inggris. data sekunder, dan 11 (2,63\%) data interjeksi onomatope. Temuan penelitian ini menunjukkan bahwa teknik penerjemahan yang banyak digunakan penerjemah untuk menerjemahkan kata seru dalam bahasa Inggris adalah penerjemahan secara literal dan penerjemahan dengan teknik pinjaman. Sebaliknya, teknik terjemahan yang paling jarang digunakan adalah teknik penjumlahan yang jarang digunakan penerjemah untuk menerjemahkan kata seru tersebut.

Kata kunci: interjeksi, terjemahan interjeksi, Looking for Alaska, Mencari Alaska, teknik penerjemahan

\section{INTRODUCTION}

In this 21st century, people can access so much information through media from all over the globe, such as the internet, television, books, movie, and other literary works. Furthermore, English was known as an international language, which makes the information covered in English in almost all information in this world. Therefore, it is a necessity to master and learn English to understand the information. In this case, translation is needed, and it becomes an important key to bridge the gap of understanding a language. With translation, the idea or message from the information is transferred from one language into another, so that the audience from the targeted language can easily get the information from the source of information.

The word translation itself has been defined in many ways by the expert, and one of them is Munday. Munday (2001: 4) states that "translation" has several meanings; it can refer to the general subject field, the product (the text that has been translated), or the process (the act of producing the translation, otherwise known as translating).

Ameka (1992) categorized interjection into some concept; there are primary, secondary, and onomatopoeic interjections. Primary interjections are individual words, which are standalone from another word class, and used only as interjections and do not stand in the syntactic structure; some examples of primary interjections are; ah, eww, ouch, oh, and so on. Secondary interjections "are those words that have an independent semantic value but which can be used as utterances by themselves to express a mental attitude or state" (Ameka 1992: 111). Secondary interjections are expressions that refer to oaths, swear words, and greetings, e.g., bless you, congratulations, good grief, hey, hi, oh my, oh my God, oh well, rats, and 
shoot. Moreover, it is onomatopoeic, which means an interjection that imitates sound, e.g., boom, bang, woof, and meow.

Speaking of media, almost all of the literary works is an informal text, and in this case, "Looking for Alaska" is one of the most famous novels in 2005, which was written by John Green and published by Dutton Juvenile. This novel becomes the winner of the Michael L. Printz Award in 2006, given by the American Library Association. Due to the occurrence of influential languages and explicit scenes, and later it becomes the most challenged book in 2005, based on the American Library Association list.

The first novel was released with an English version. However, after some time, many publishers are starting to release the book into various languages, especially the Bahasa Indonesia version, published by Gramedia into "Mencari Alaska". Due to the different languages, this novel has been undergoing a process of translation, in this case, "Looking for Alaska" into "Mencari Alaska", or English into Indonesian. Based on the interesting fact above, the researchers assume that to convey and transfer the message from Source Language (SL) into Target Language (TL), translation is needed. It is one of the essential aspects to conduct this research because the research subject is about translating English interjections into Indonesian interjections.

Long before this study was conducted, there are two previous studies on interjections translation. Firstly, it was conducted by Septiana (2016) in her thesis entitled A Translation Analysis of Interjections in "Harry Potter and The Sorcerer's Stone. This study mainly aims at examining translation techniques applied by the translator and their influence to the translation quality in terms of accuracy and acceptability in the novel. The research gap between this study and the previous one is that the source data of this study is less popular. The novel "Looking for Alaska" is known worldwide in 2005, while the novel "Harry Potter and the Sorcerer's Stone is much known later on. Aside from the fame difference, the findings show quite a few similarities in terms of the dominant translation technique applied and the least one applied; they are Literal Technique on top and Naturalized Borrowing on the bottom. Secondly, to do the research and analyze the data, the researchers implemented the translation techniques in translating interjections from the previous researchers of interjection study, which entitles Interjection Translation found in the Bilingual Comics of the Very Best of Donald Duck Comics 15th Edition by Nurwati (2015), in that study, she used translation techniques from Cuenca, and Vinay and Dalbernet. The main reason that the researchers used those translation techniques from the previous research is because of the compatibility and suitability to identify the methods used by the translators in translating English into Indonesian interjection. Besides, the researchers added Molina and Albir's translation techniques to identify and analyze the translation techniques of interjection, especially in defining the borrowing techniques into two parts, which are pure borrowing and naturalized borrowing translation techniques.

After the researchers finished reading all of the two English versions and its translated version of Bahasa Indonesia in the novel "Looking for Alaska", the researchers were interested in conducting a research about English and Indonesian interjection, which Green and the Indonesian translators used in that novel. The experts explain that interjection is one of the eight significant parts of speech, which function to express emotion. However, it has no grammatical relations with other words in a sentence. An interjection, known as an exclamation, which is formed in a word, phrase, or sound is used to convey and express an emotion such as surprise, excitement, happiness, or anger. Therefore, while the researchers read the novel, he found out various kinds of interjection in the novel "Looking for Alaska", 
which later, the researchers provide an analysis and overview of the meanings, functions, categories of interjections, and the translation techniques which the Indonesian translator used to translate English interjection.

From the fact above, the novel "Looking for Alaska" is an informal text. So, interjection can be easily found in the book. This research is aimed to analyze the translation of interjection based on the novel "Looking for Alaska". Some examples of the interjection analysis can be seen in the discussion below:

Interjections consist of three primary classifications, and they categorized into expressive interjection, which focuses on the speaker's state of emotions, the conative interjection, with emphasis on the speaker's wishes and the phatic interjection which has to do with the establishment of contact. In this study, the researchers implement the interjection translation analysis based on those interjection classifications, due to their numbers of appearances found in the novel. There are some examples and explanation of expressive, conative, and phatic interjections which will be analyzed down below.

Expressive or emotional interjections categorized as vocal gestures, which are symptoms of the speaker's mental state. It divided into two groups: the emotive and the cognitive. The emotive mental states are those that express the speaker's state concerning the emotions and sensations they have at the time. For example, "Yuk! I feel disgusted"; "Wow! you are amazing,"; "Ouch! That hurt,"; "Ugh! That thing is disgusting" meanwhile, the cognitive Interjections are an interjection that is stating the knowledge and thoughts at the time of utterance are expressed. Examples include: "Aha! I got you"; "ehe! I forgot." Below are some explanations and examples of expressive interjections taken from https://allnovel.net/looking-for-alaska.html.

Example 1

SL : "Hey!" Alaska interrupted. "It was my idea!"

TL : "Hey!" sahut Alaska. "Itu ideku!"

Example 2

SL : “Oooooh, really? Well, jeez, then it's brilliant," I answered.

TL : “Oooooh, benarkah? Kalau begitu, wow, puisinya hebat,” jawabku.]

Most interjections, typically found in non-formal conversation, which found in various literary works such as in the novel (in the case of Excerpt 1 and 2). Mostly, interjections formed in the first or initial sentence followed with a comma or exclamatory signs. Although some interjections also placed in the middle of a phrase or sentence (e.g., Example 2) and it sometimes appears in the final of the sentence (e.g., Not bad, $\boldsymbol{e h}$ ?). Interjections are also known as an "independent," word. It is so-called independent due to a lack of relations between interjections with any other "word classes" in terms of grammatical construction and syntactical relationship (Jovanovic, 2004:21). In some cases, interjections are placed in the front of exclamatory sentences (e.g., Example 1).

Conative interjections are those expressions that are directed at an auditor. They aimed at getting someone's attention, or they demand action or response from someone of a speaker's wants. "The aim of conation," as Isacenko (1964: 91) points out, "is to provoke a reaction on the part of the listener." For example, "sh! Can you please be quiet?"; "eh? What did you 
say earlier?".' Below are some examples of conative interjections taken from taken from https://allnovel.net/looking-for-alaska.html. :

Example 3

SL : "Shh. Shh. Don't ruin it."

TL : "Shh. Shh. Jangan rusak momen ini."

Phatic interjections generally used in the establishment and maintenance of communicative contact. A variety of common vocalizations that express a speaker's mental attitude towards the on-going discourse, that is, back channeling or feedback signaling vocalizations, may be classified as phatic. From https://allnovel.net/looking-for-alaska.html. the phatic interjections $\boldsymbol{m h \boldsymbol { m }} \boldsymbol{\boldsymbol { u h }} \mathbf{h} \boldsymbol{h} \boldsymbol{h}, \boldsymbol{y e a h}$ are as examples. Included in this class are interjections used in the performance of various interactional routines.

Example 4

SL : “God, we'll miss you,"

TL : "Ya Tuhan, kami akan merindukanmu."

Translating interjection is a difficult task to do, the cause of those difficulties of translation process relates to the contextual and cultural background of Source Language (SL). The researchers tried to resolve those translating problems, especially in translating interjection, the translators are intended to understand the culture, context, and dialect of the source language. It would not be a surprising phenomenon if a translator got confused when translating an interjection. They get confused due to a lack of understanding in both source language and target language. Translating an interjection is confusing whether it is a natural or unnatural type of translation; for the example, "God" in case Excerpt 4 is being translated into a similar text or similar in lexical meaning, which means that an English interjection "God" lexical meaning is not changing in Indonesian interjection. From https://allnovel.net/looking-for-alaska.html. in the novel, the researchers found out various English interjection "God," which has Indonesian translation different lexical meaning from the target text, such as:

Example 5

SL : "God, that's awful. I shouldn't laugh. But I will,"

TL : "Ya ampun, kasihan sekali. Aku tidak seharusnya tertawa. Tapi aku akan tetap tertawa,"

Example 6

SL : "God, I understand whale anatomy. Can we move on now, Herman?"

TL : "Astaga, aku paham anatomi paus. Bisakah kita lanjutkan Herman?"

Example 7

SL : “...Last Thanksgiving, I spent the whole time constructing one massive 
candle using the wax from all my little candles. God, it was boring. I counted the ceiling tiles..."

TL : “...Thanksgiving tahun lalu, aku menghabiskan waktu dengan menyusun satu lilin besar dari semua lilin kecil yang kumiliki. Bosan banget. Aku menghitung petak langitlangit..."

From the examples above, it is concluded that the examples 5, 6, and 7 have an identical interjection form in source language, e.g., an interjection "God," but, when it comes to the Indonesian translation, the interjection is shifting and becoming a different in its structure, such as "God" translated into "ya ampun," "astaga," "Ya Tuhan," and even it was omitted (e.g., Example 7). What makes the outcome of the translating interjection different is because of the difference in the contextual meaning of the interjection, and it also has different translation techniques. After learning and finding the phenomena of interjections translation above, the researchers intended to expand and overview more of how interjections developed in the novel of "Looking for Alaska" in terms of functions, meanings, and categories of Ameka's interjections theory through Molina \& Albir translation techniques. The researchers also set an objective of this research based on the research background above, which focused on translation analysis of an English interjection in "Looking for Alaska" and their Indonesian translation in " Mencari Alaska"." based on Ameka's interjections theory.

\section{METHOD}

\section{Data and Subject}

The data of this research were John Green's novel "Looking for Alaska" and the Indonesian translation "Mencari Alaska" by Barokah Ruziati and Ayu Wulandari as the subject of the study.

\section{Unit of Analysis}

The unit of analysis in this research is the discussion about translation of interjection in terms of functions, meanings, and categories in the novel "Looking for Alaska", and its Indonesian translation of "Mencari Alaska".

\section{Method of Data Collection and Analysis}

Creswell states that there are four types of data collection; those types are observations, interviewing to the subject of the research, documents, and audiovisual materials (Creswell,1998:120). In this research, the researchers used the document method because the source of data is in the form of a novel or also known as content analysis. Sutopo states that "the written documents and archives have important roles in qualitative research. It is also called the content analysis" (2002:69).

In regard to the sampling technique, the researchers used the purposive sampling method. It means that the sample which was taken and analyzed is the data that represent the subject of the research. The researchers collected and analyzed the interjections in both English and Indonesian versions of "Looking for Alaska", which considered as being able to represent the information studied. In qualitative research, this sampling method is not aimed to 
generalize the population, yet it is functioned to get an in-depth study in a specific context (Sutopo 2002:37).

The research procedure is a set of activities that are done by the researchers in conducting the research. The processes of the study are, determining the research topic, which is interjection as the main subject of this research. Determining the source of data, that is the novel entitled "Looking for Alaska" and its Indonesian translation "Mencari Alaska". The researchers gather two books from John Green's entitled "Looking for Alaska" published by Dutton Juvenile in New York, and it is the Indonesian version entitled "Mencari Alaska" translated by Barokah Ruziati \& Sekar Wulandari, published by Gramedia. The researchers read and collected all of the data of interjections found in the novel "Looking for Alaska" from both original English edition and translated Indonesian version of "Mencari Alaska". The researchers coded the data collected from the novels. For example:

SL: “God, we'll miss you” (012/LA/007)

\section{TL: "Ya Tuhan, kami akan merindukanmu” (012/MA/013)}

SL is the abbreviation of Source Language, and TL is the abbreviation of Target Language, (012/--/--) refers to the number of data, (--/LA/--) refers to the English novel "Looking for Alaska", (--/MA/--) refers to the Indonesian book "Mencari Alaska", (--/--/007) refers to the page number of the SL interjection from the English edition, (--/--/013) refers to the page number of the TL interjection in the Indonesian novel.

After collecting the data, the researchers analyzed the interjection data based on their distinctive functions, meanings, and categories, then calculate the percentage of each interjection and present the data in the form of a table. Then the researchers analyzed and classify the data based on the techniques applied by the translator. The following step is calculating the data to find out the percentage of the use of each technique by presenting it in the form of a table. Lastly, the researchers described the findings of the study and also conclude the results of the study with some suggestions to be proposed.

\section{RESULTS AND DISCUSSION}

\section{Results}

Table 1 is the results of the interjection in terms of functions and meanings found in John Green's novel "Looking for Alaska".

Table 1 Interjection classification in terms of meanings and functions found in the novel "Looking for Alaska"

\begin{tabular}{llcc}
\hline No. & Interjection classification & Total data & Percentage (\%) \\
\hline 1. & Interjections for greeting & 5 & $1,19 \%$ \\
2. & Interjections for joy & 35 & $8,35 \%$ \\
3. & Interjections for attention & 57 & $13,37 \%$ \\
4. & Interjections for approval & 169 & $40,33 \%$ \\
5. & Interjections for surprise & 120 & $28,64 \%$ \\
6. & Interjections for sorrow & 34 & $8,11 \%$ \\
\hline \multicolumn{2}{r}{ TOTAL } & $\mathbf{4 1 9}$ & $\mathbf{1 0 0 , 0 0 \%}$ \\
\hline
\end{tabular}


Table 1 above shows an interjection based on the www.englishbix.com, and is taken from Cuenca's classifications and definitions of interjections. They are divided into six basic human feelings classification and implemented as types of interjections based on how they are functioning. These six types of interjections occur to express human emotion through various expressions, and they are interjections for greeting, joy, surprise, approval, attention, and sorrow. The researchers found out that there is a total of 419 data of interjections that have been collected and analyzed based on the terms of functions and meanings.

Table 2 Interjection based on the categories found in the novel "Looking for Alaska"

\begin{tabular}{llcc}
\hline No. & Interjection classification & Total data & Percentage (\%) \\
\hline 1. & Primary interjection & 72 & $17,18 \%$ \\
2. & Secondary interjection & 336 & $80,19 \%$ \\
3. & Onomatopoeic interjection & 11 & $2,63 \%$ \\
\hline \multicolumn{2}{c}{ TOTAL } & $\mathbf{4 1 9}$ & $\mathbf{1 0 0 , 0 0 \%}$ \\
\hline
\end{tabular}

Taken from Table 2 above, there are many kinds of interjection found in the novel "Looking for Alaska," which can be divided into three interjection classes or categories. Those categories are primary, secondary, and onomatopoeic interjection. Based on the research of interjection in terms of category, there is a total of 419 data of English interjections which the researchers divide into three classes, those classes are $72(17,18 \%)$ data of primary interjection, $336(80,19 \%)$ data of secondary, and $11(2,63 \%)$ data of onomatopoeic interjection.

Table 3 Translation techniques found in the novel "Looking for Alaska".

\begin{tabular}{|c|c|c|c|}
\hline No. & Translation Techniques & $\begin{array}{l}\text { Total } \\
\text { data }\end{array}$ & $\begin{array}{l}\text { Percentage } \\
(\%)\end{array}$ \\
\hline 1. & Literal translation & 164 & $41,21 \%$ \\
\hline & $\begin{array}{l}\text { Translation by using an interjection with similar } \\
\text { meaning and form. }\end{array}$ & 49 & $12,31 \%$ \\
\hline 3. & $\begin{array}{l}\text { Translation by using an interjection with } \\
\text { different forms but the same meaning. } \\
\text { Omission }\end{array}$ & 61 & $15,33 \%$ \\
\hline & $\begin{array}{l}\text { a. Partly deleted } \\
\text { b. Totally deleted }\end{array}$ & $\begin{array}{c}11 \\
9\end{array}$ & $\begin{array}{l}2,76 \% \\
2,26 \%\end{array}$ \\
\hline 5. & Addition & 8 & $2,01 \%$ \\
\hline & $\begin{array}{l}\text { Borrowing } \\
\text { a. Pure borrowing } \\
\text { b. Naturalized borrowing }\end{array}$ & $\begin{array}{l}58 \\
53\end{array}$ & $\begin{array}{l}10,80 \% \\
13,32 \%\end{array}$ \\
\hline & $\begin{array}{ll}\text { TOTAL } \\
\end{array}$ & 413 & $100,00 \%$ \\
\hline
\end{tabular}

Table 3 discusses the translation techniques used by the translators in translating English into Indonesian interjection found in the novel "Looking for Alaska" and their Indonesian translated version, "Mencari Alaska". 
In data analysis, the researchers give some examples and explanations of the interjection translation technique from John Green's novel "Looking for Alaska".

\section{Discussion}

According to the research findings or the results of interjections translation technique analysis, the discussion shows the technique of interjection translation in terms of functions, meanings, and categories of English interjection and their Indonesian translations found in the novel "Looking for Alaska".

\section{Interjection in terms of function and meaning}

\section{Interjections for greeting}

An interjection of greeting is the type of interjection which used to express and to indicate warmth feelings or emotions toward a person.

\section{Excerpt 1}

SL : I found myself saying, "Hey." (235/LA/079)

TL : Kudapati diriku berkata, "Hei!" (235/MA/133)

\section{Interjections forjoy}

An interjection of joy is the type of interjection used to express and to indicate happiness and joy toward a person, situation, or something related.

\section{Excerpt 2}

SL : "That's pretty good," the Colonel said. (256/LA/071)

TL : "Lumayan bagus," katanya, (256/MA/111)

\section{Interjections for attention}

An interjection of this type is used to get attention from someone.

Excerpt 3

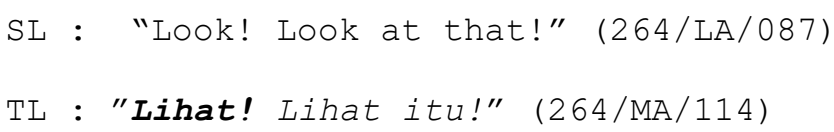

\section{Interjections for approval}

An interjection of this type is used in the sentence to show the strong sense of consent or agreement for something that has happened.

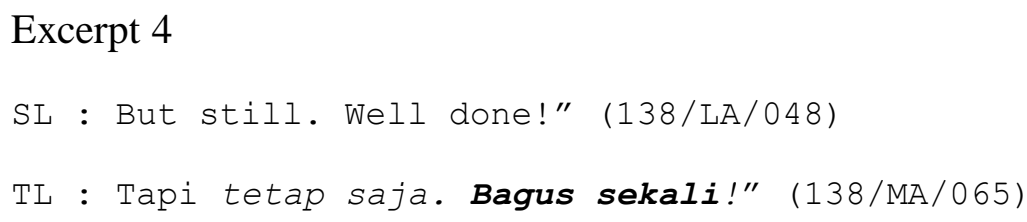




\section{Interjections for surprise}

An interjection of greeting is the type of interjection which used to express and to indicate warmth feelings or emotions toward a person.

Excerpt 5

SL : "Oh, God, no. No. No..." (514/LA/182)

TL : "Oh, Tuhan, tidak. Tidak. Tidak..." (514/MA/229)

\section{Interjections for sorrow}

An interjection of sorrow is the type of interjection used in the sentence to express the emotion of sadness about something unfortunate has happened.

Excerpt 6

SL : "Oh, sweetie. We miss you so much." (226/LA/077)

TL : "Oh, sayang. Kami sangat merindukanmu." (226/MA/101)

\section{Interjection in terms of categories}

\section{Primary interjections}

Primary interjections are single words that cannot stand alone without supporting the sentence behind it.

\section{Excerpt 7}

SL : "Oooooh, really?..." (272/LA/089)

TL : "Ooooh, benarkah?..." (272/MA/116)

\section{Secondary interjection}

Secondary interjections are interjections coming from other words classes.

\section{Excerpt 8}

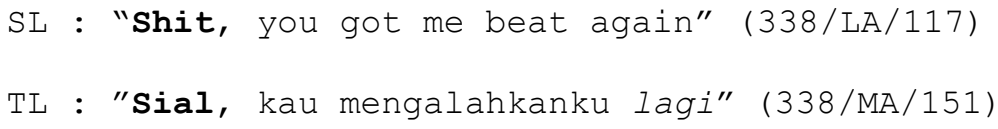

\section{Onomatopoeic interjection}

An onomatopoeic interjection is an interjection that imitates a sound.

Excerpt 9

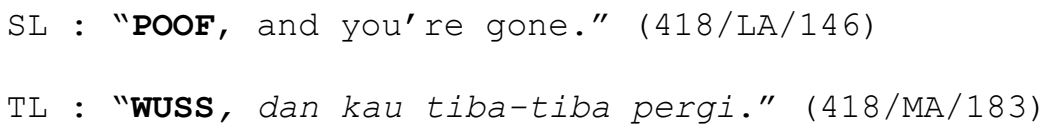




\section{Translation techniques of interjection}

\section{Literal translation}

The literal translation used in the research due to the techniques is about transferring the message from ST into TT without changing the meaning, and it also does not change the lexical items of the interjection itself.

Excerpt 10

SL : "Wait. Wait," she said... (088/LA/028)

TL : "Tunggu, tunggu," katanya... (088/MA/039)

Translation by using an interjection with similar meaning and form

The translation technique by utilizing a parenthesis with the same purpose and structure is intended to find and identify an interjection that has similar meaning and structure from both ST and TT in the novel "Looking for Alaska" and "Mencari Alaska".

Excerpt 11

SL : "Yup. Get ready for..." (160/LA/051)

TL : "Yap. Bersiaplah..." (160/MA/069)

\section{Translation by using an interjection with different forms but the same meaning}

The translation technique, by using an interjection with a different style but has a similar purpose, this technique is intended to find and identify an interjection that has the same meaning, but it has changed in lexical form.

Excerpt 12

SL : "God, that's awful... (062/LA/018)

TL : "Ya ampun, kasihan sekali ...(062/MA/027)

\section{Omission}

The translators partially omit or totally omits some parts of pieces of information, especially an interjection from the ST into the TT.

Excerpt 13

SL : "Oh well. There's always tomorrow." (159/LA/051)

TL : "Yah, selalu ada hari esok." (159/MA/068)

\section{Addition}

This translation technique used by the translators by adding an interjection element within the TL. 
Excerpt 14

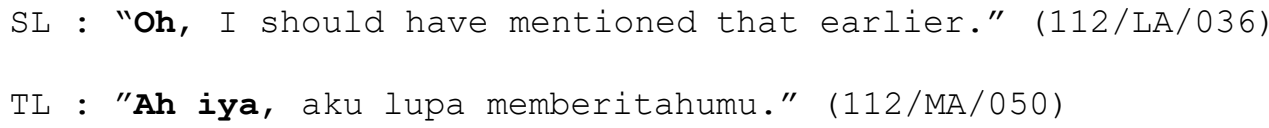

\section{Borrowing}

Borrowing translation technique used by the translators in translating an interjection by borrowing the same form and meaning of interjection from ST.

Excerpt 15

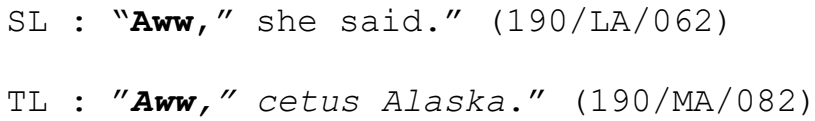

\section{CONCLUSION}

The findings are shown in conclusion that there are six translation techniques used by the translators to translate interjections, six kinds of interjections in terms of functions and meanings, and three kinds of interjections in terms of categories found in the novel "Looking for Alaska" into Indonesian "Mencari Alaska".

Adopting the translation technique of interjection from Baker (1992), Molina \& Albir (2002), and Cuenca (2006), the researchers found out that the techniques with high degree of accuracy are translation by literal translation and translation by using an interjection with similar meaning and form. Meanwhile, the other lesser degrees of accurate translation are translation by using an interjection with different forms, but the same meaning, partly deleted omission technique, total deleted omission technique, addition technique, pure borrowing technique, and naturalized borrowing technique.

Last but not least, the researchers hope that Indonesian learners who are likely to be translating interjections from English into Indonesian should be aware of the differences of the set so that they will not make more mistakes, or in this context, translating mistakes due to the differences. For all of the readers, the researchers also hope that by this study, it will prove that interjection is not the only piece of words, but it has a complex function, meaning, and categories.

\section{REFERENCES}

Ameka. (2006). Interjections. https://studylib.es/doc/8793077/ameka---2006--interjections. Accessed on October 13, 2019.

Baker, Mona. 1991. In Other Words: A Course Book on Translation. London: Routledge.

Creswell, J. W. (1994). Research Design: Qualitative and Quantitative Approaches.Thousand Oaks. CA: Sage.

Cuenca, Maria.J. (2004). Translating interjections: an approach from grammaticalization theory. http://72.14.203.104/search?q=cache:YdK4P2cu6aUJ:www.facfil.ucp.pt/ 
Cuenca.abstract.doc+interjection+translation $\& h \mathrm{l}=\mathrm{id} \& \mathrm{gl}=\mathrm{id} \& \mathrm{ct}=\mathrm{clnk} \& \mathrm{~cd}=9$ \&ie $=U T F-8$. Accessed October 18, 2019.

Equivalence and Equivalent Effect in Translation Theory essay. https://www.essay.ws/equivalence-and-equivalent-effect-in-translation-theoryessay/. Accessed on October 18, 2019.

Exploring Variation and Dispositional Choice in Translation. http://fib.ub.ac.id/iconlaterals/wp-content/uploads/2016/12/Nur-Rosita.pdf. Accessed on October 18, 2019.

H.B. Sutopo. (2002). Pengantar Penelitian Kualitatif. Surakarta : Universitas Sebelas Maret Press.

(2002). Metodologi Penelitian Kualitatif: Dasar Teori dan Terapannya dalam Penelitian. Surakarta: UNS Press.

. (1998). Qualitative Inquiry and Research Design: Choosing among. Five Tradition. London: Sage Publications.

Hornby, A.S., 1995. Oxford Advanced Learner's Dictionary of Current English. Oxford: Oxford University Press.

2000. Oxford Advance Learner's Dictionary of Current English.UK: Oxford University Press.

https://www.rushtermpapers.com/identify-three-of-the-most-salient- $\quad$ aspects-of-the-tendistinguishing-characteristics-of-qualitative-writing/. Accessed on October 18, 2019.

Interjections The universal yet neglected part of speech. https://pure.mpg.de/rest/items/item_855720/component/file_855719/c ontent. Accessed on October 13, 2019.

http://eprints.brighton.ac.uk/14639/1/Interjections-Wharton.pdf. Accessed on October 13, 2019.

Looking for Alaska - Read Novels Online. https://allnovel.net/looking-for- alaska.html. Accessed on September 21, 2019.

Lord Woodhouselee - Principles of Translation | Language Realm. http://www.languagerealm.com/articles/lord_woodhouselee.php. Accessed on October 13, 2019.

Nababan, M.R. (2003). Teori Menerjemah Bahasa Inggris. Jogjakarta: Pustaka Pelajar.

Nida, E. A. \& Taber, C. R. (1974). The Theory and Practice of Translation. Published for the United Bible Societies by. E. J. Brill.

Nurwati, Ayu. (2014). Translation Analysis Of Interjections Found In Bilingual Comics Of The Very Best Of Donald Duck Comics 15th Edition. Surakarta: Faculty of Humanities Sebelas Maret University. 
Onomatopoeia Examples, Definition, and Worksheets | KidsKonnect. https://kidskonnect.com/language/onomatopoeia-examples/ Accessed on December 01, 2019.

Poerwadarminta, W.J.S. 1985. Kamus Umum Bahasa Indonesia. Jakarta: PN Balai Pustaka.

Schaaffner, C. (1997). "From 'Good' to 'Functionally Appropriate': assessing Translation Quality." Current Issues in Language and Society. Vol. 4, No 1, 1-5. Available at http://www.multilingualmatters.net/cils/004/0001/cils0040001.pdf. Accessed on October 19, 2019.

Septiana, Trisna. (2016). Translation Analysis of Interjections in Harry Potter and the Sorcerer's Stone. Thesis. English Department: Faculty of Cultural Science Sebelas Maret University.Surakarta.

Suryawinata, Zuchridin and Hariyanto, Sugeng. (2003). Translation: Bahasan Teori dan Penuntun Praktis Menerjemahkan. Jogjakarta: Kanisius.

Sutopo, H.B. 2002. Metodologi Penelitian Kualitatif. Surakarta: Sebelas Maret University Press

The History of Translation Techniques English Language Essay. https://www.uniassignment.com/essay-samples/english-language/the- history-oftranslation-techniques-english-language-essay.php. Accessed on October 13, 2019.

Translation Techniques According to Molina and Albir. http://www.itslista.web.id/2018/05/translation-technique.html. Accessed on October 13, 2019. 